\title{
Effect of Naturally Acidic Agents on Microhardness and Surface Micromorphology of Restorative Materials
}

\author{
Chanothai Hengtrakoola \\ Boonlert Kukiattrakoon ${ }^{\text {b }}$ \\ Ureporn Kedjarune-Leggat ${ }^{c}$
}

\begin{abstract}
Objectives: This study investigated the titratable acidity and erosive potential of acidic agents on the microhardness and surface micromorphology of four restorative materials.

Methods: Forty-seven discs of each restorative material; metal-reinforced glass ionomer cement (Ketac-S), resin-modified glass ionomer cement (Fuji II LC), resin composite (Filtek Z250) and amalgam (Valiant-Ph.D.), $12 \mathrm{~mm}$ in diameter and $2.5 \mathrm{~mm}$ in thickness, were divided into four groups (5 discs/group). Specimens were then immersed for 7 days into four storage media; deionized water (control), citrate buffer solution, green mango juice and pineapple juice. Microhardness testing before and after immersions was performed. Micromorphological changes were evaluated under a scanning electron microscope (SEM). Statistical significance among each group was analyzed using two-way repeated ANOVA and Tukey's tests.

Results: The Fuji II LC and the Ketac-S showed the highest reduction in microhardness ( $\mathrm{P}<.05)$. The Valiant-Ph.D. and the Filtek Z250 showed some minor changes over the period of 7 days. The mango juice produced the greatest degradation effect $(P<.05)$.

Conclusions: This study suggested that for restorations in patients who have tooth surface loss, materials selected should be considered. In terms of materials evaluated, amalgam and resin composite are the most suitable for restorations. (Eur J Dent 2011;5:89-100)
\end{abstract}

Key words: Resin composite; Restorative material; Surface microhardness; Titratable acidity.

a Assistant Professor, Prince of Songkla University, Faculty of Dentistry, Department of Conservative Dentistry, Hat Yai, Songkhla, Thailand.

b Associate Professor, Prince of Songkla University, Faculty of Dentistry, Department of Conservative Dentistry, Hat Yai, Songkhla, Thailand.

c Associate Professor, Prince of Songkla University, Faculty of Dentistry, Department of Oral Biology and Occlusion, Hat Yai, Songkhla, Thailand.

- Corresponding author: Dr. Boonlert Kukiattrakoon Prince of Songkla University, Faculty of Dentistry, Department of Conservative Dentistry, 15 Kanchanavanich Rd, Hat Yai, Songkhla 90112, Thailand. Phone: +6674287703 Fax: +6674429877

E-mail: boonlert.kapsu.ac.th

\section{INTRODUCTION}

Tooth surface loss results in the functional loss of tooth tissues including enamel, dentin, and cementum. This may lead to severe alteration of occlusion and damage to restorative materials. It can occur due to abrasion (physical wear by objects or substances other than teeth), attrition (direct tooth-to-tooth rubbing), or erosion (non bacterial acid dissolution). However, in most individual cases, it is difficult to ascribe the cause of tooth surface loss to any one category of etiology. ${ }^{1,2}$ Currently, erosion is believed to be the 
most common cause of tooth surface loss, even though it is not easy to make a definitive diagnosis in this regard. ${ }^{2}$ The distribution of tooth surface loss caused by erosion shows a predominance on occlusal surfaces lespecially the mandibular first molars), followed by facial surfaces (the anterior maxillary teeth). ${ }^{3}$ The clinical appearances of erosion include broad concavities within smooth surface enamel, cupping of occlusal surfaces or incisal grooving with dentin exposure, and increased incisal translucency. ${ }^{2}$

When a patient suffers from tooth surface loss, restorative treatment should be considered. Common complaints include dentine hypersensitivity and an unacceptable esthetic condition, and a pulpal exposure is also likely. ${ }^{2}$ Hence, an appropriate restoratives treatment must be chosen. The materials used should form an intimate adaptation with cavity interfaces to resist microleakage and the influx of oral irritants. In other words, the restoration should not lead to postoperative sensitivity, interfacial staining, or recurrent caries.

A variety of restorative materials are currently recommended for erosive lesions, including glass ionomer cement, reinforced glass ionomer cement, resin-modified glass ionomer cement, resin composite, and amalgam. ${ }^{4}$ Each material has its own advantages and disadvantages, which are considered before selecting them as restorative materials. Resin composite is a mixture of polymers or resins and glass particles or fillers. It is based on a polymethacrylate resin matrix along with a silane-coated, inorganic filler. ${ }^{5}$ Resin composites can bind to the tooth structure and provide an acceptable esthetic result. However, resin composite is not effective in restoring large defects in posterior teeth, including its technical sensitivity to moisture. Glass ionomer cement, mainly composed of calcium fluoroaluminosilicate glass in a powder form, reacts with aqueous polyacrylic acid or related polymeric acids. ${ }^{6}$ It is especially effective for treating erosive lesions because of its potential to release fluoride ions into the underlying dentine to protect tooth structure. In addition, it provides the ability of forming chemical bonds to the enamel and the dentin. However, glass ionomer cement is susceptible to fracture and exhibits low wear resistance. ${ }^{7}$ One of the development of glass ionomer cement was cermet cement (metal-reinforced glass ionomer cement) performed by McLean and Gasser. ${ }^{8}$ This process fixed the ratio of glass to silver at 60:40 (w:w). The silver particles would improve certain mechanical properties of the cement and increase its wear resistance..$^{9,10}$

Resin-modified glass ionomer cement was recently introduced as a restorative material. Polyacids in a conventional glass ionomer cement were modified with a pendant methacrylate group. ${ }^{11}$ Some studies claimed that it improved the mechanical properties of resin-modified glass ionomer cement. ${ }^{12,13}$ However, resin-modified glass ionomer cement, used particularly for occlusal restoration, still has a high rate of degradation when compared to resin composite and amalgam. ${ }^{5,14}$ Amalgam has been used as a restorative material for almost 200 years. Amalgam is an alloy made from reacting mercury with silver, tin, and copper. ${ }^{14}$ Although amalgam has good physical properties for posterior restoration, it requires mechanical retention and more tooth preparation than other materials.

The acid resistance property is another criterion considered while selecting materials for restoring erosive lesions. Previous studies have shown that some dietary foods and beverages that are chemically acidic can cause surface degradation of restorative materials. ${ }^{13,15,16}$ These acidic foods and beverages can alter the surface hardness of glass ionomer cement, but cause only minor changes to the resin composite. ${ }^{16}$ Little is known about the effect of dietary acids on other restorative materials, such as metal-reinforced glass ionomer cement and amalgam.

Beverages tested in previous studies ${ }^{13,15,16}$ include orange juices, apple juice, and cola soft drinks; the acids most frequently found in these juices are citric, malic and phosphoric and carbonic acids, respectively. ${ }^{17-19}$ In general, the habit of eating or chewing sour fruits, such as green mangoes, pineapples, and limes, is most commonly found in tropical countries such as Australia, Cuba and some countries in Southeast Asia. ${ }^{20-23}$ One study conducted in Thailand, ${ }^{23}$ with an emphasis on the southern region, showed that the risk factors associated with tooth wear included age, gender, number of teeth lost, frequency of alcohol consumption, carbonated drinking, and especially sour fruit intake. Previous studies have shown that some beverages (cola soft drinks, apple juice, and 
orange juices) are harmful to restorative materials (glass ionomer cement and resin composite), 13,15,16 but little is known about the effect of these sour fruits (green mangoes and pineapples) on other restorative materials (metal-reinforced glass ionomer cement and amalgam). Frequent intake of sour fruit may affect these restorative materials. Therefore, the purpose of this study was to investigate the erosive potential and the titratable acidity of several acidic agents (sour fruit juices) on the surface hardness of four restorative materials: metal-reinforced glass ionomer cement, resinmodified glass ionomer cement, resin composite, and amalgam. The null hypothesis tested was that there was no difference in the surface microhardness of the four restorative materials after immersion in the acidic agents being tested.

\section{MATERIALS AND METHODS}

For this study, four types of commercial restorative materials were chosen. These included a metal-reinforced glass ionomer cement (Ketac Silver Aplicap (Ketac-S)), a resin-modified glass ionomer cement (Fuji II LC), a resin composite (Filtek Z250), and an amalgam (Valiant-Ph.D.). The details of these materials are given in Table 1. Fuji II LC, supplied in a powder/liquid form, was used as the hand-mixing material. The Ketac-S and the Valiant-Ph.D. were obtained as pre-loaded capsules, and were mixed using an electrical tritulator (ProMix, Dentsply DeTray GmbH, Konstanz, Germany) at $4300 \mathrm{~Hz}$ for 10 seconds. The Fuji II LC and the Filtek $Z 250$ were polymerized for $40 \mathrm{sec}-$ onds with a light-activated polymerization unit. The light intensity was verified with a measuring device (Cure Rite, L.D. Caulk, Milford, DE, USA).

\section{Specimen preparation}

Using a polytetrafluoroethylene cylindrical mold $(12 \mathrm{~mm}$ in diameter and $2.5 \mathrm{~mm}$ in thickness), forty-seven specimens of each restorative material were made. A polyethylene sheet and a glass slide were then placed over the filled mold after which light pressure was applied. The glass slide and the polyethylene sheet had mirrorflat surfaces. This method was able to provide a smooth surface on each specimen. The specimens were allowed to mature in their molds in an incubator at $37^{\circ} \mathrm{C}$ for 1 hour after mixing. No mechanical preparation or abrasions of specimens was performed.

\section{Storage media preparation and titratable acidity}

Four storage media were used in this study: deionized water (control), citrate buffer solution (comparator), green mango juice (Magnifera indica L.), and pineapple juice (Ananas comosus L.). These juices were prepared from fresh pineapples and mangoes using a juicer and then sieved with double layers of filter cloth. Sufficient amount of juices were prepared at once to last through the entire experiment. The juices were stored in a refrigerator throughout the experiment. The $\mathrm{pH}$ of each storage media (except the deionized water) was determined using a $\mathrm{pH}$ meter (Orion 900A, Orion Research, Boston, MA, USA). Ten pH readings of the freshly prepared juices were obtained in order to give a mean $\mathrm{pH}$ measurement for each solution.

To determine titratable acidity (buffering capacity), ${ }^{24} 20 \mathrm{~mL}$ of each acidic agent was added by $0.5 \mathrm{~mL}$ increments of $1 \mathrm{~N}$ sodium hydroxide $(\mathrm{NaOH})$. The amount of $\mathrm{NaOH}$ required to reach $\mathrm{pH}$ levels of 5.5, 7.0, and 10.0 was recorded. The

Table 1. Restorative materials used in this study

\begin{tabular}{|c|c|c|c|c|c|c|}
\hline Product & Type of material & Main constituents & Mixing & Setting reaction & Batch no. & Manufacturer \\
\hline Ketac-S & $\begin{array}{l}\text { Conventional } \\
\text { reinforced glass } \\
\text { ionomer cement }\end{array}$ & Silver $(40 \% \mathrm{w} / \mathrm{w})$ & Capsulated & $\begin{array}{l}\text { Acid-base } \\
\text { reaction and } \\
\text { free-radical } \\
\text { polymerization }\end{array}$ & 139517 & 3M ESPE, St. Paul, MN, USA \\
\hline Fuji II LC & $\begin{array}{l}\text { Resin-modified } \\
\text { glass ionomer } \\
\text { cement }\end{array}$ & $\begin{array}{l}\text { Resin-modified } \\
\text { polyacrylic acid, ion } \\
\text { leachable glass }\end{array}$ & $\begin{array}{l}\text { Hand-mixed } \\
\text { (3:1 P/L) }\end{array}$ & $\begin{array}{l}\text { Acid-base } \\
\text { reaction }\end{array}$ & 202271 & GC Corp., Tokyo, Japan \\
\hline Filtek Z250 & Resin composite & $\begin{array}{l}\text { Bis-GMA, zirconia/silica } \\
\text { fillers }\end{array}$ & One-paste & $\begin{array}{l}\text { Light-activated } \\
\text { polymerization }\end{array}$ & 20021127 & 3M ESPE, St. Paul, MN, USA \\
\hline Valiant-Ph.D. & Amalgam & $\begin{array}{l}\text { Silver, tin, copper, pal- } \\
\text { ladium, mercury }\end{array}$ & Capsulated & Amalgamation & 20913 & $\begin{array}{c}\text { Dentsply Caulk, Milford, } \\
\text { DE, USA }\end{array}$ \\
\hline
\end{tabular}

Bis-GMA: 2,2-bis[4-(2-hydroxy-3-methacryloxypropoxy)phenyl]propane. 
titrations for each solution were also repeated ten times to obtain a mean value. The buffering capacity was assessed by plotting the $\mathrm{pH}$ against the quantity $(\mathrm{mL})$ of $\mathrm{NaOH}$ that was required to raise the $\mathrm{pH}$ to $5.5,7.0$, and 10.0 .

After 1 hour in an incubator, the specimens of each material were transferred into the storage media while still in their molds. The setting reaction for all materials is a complex process. The reason for keeping the molds in the incubator for one hour before exposure to solutions is an estimated time for restorations being to exposed in the oral environment. The specimens were stored in individual plastic storage pots containing $20 \mathrm{~mL}$ of the storage media, which was a sufficient volume to completely cover the specimens and the mold. The immersed specimens were retained in their molds at $37^{\circ} \mathrm{C}$ for the appropriate test period.

Microhardness testing

Twenty specimens of each restorative material were divided into four groups (5 discs/group). The hardness value $\left(\mathrm{kg} / \mathrm{mm}^{2}\right.$ ) of each specimen was determined using a microhardness tester (Micromet II, Buehler, Lake Bluff, IL, USA) with a diamond Vickers indenter. The specimens were placed on the platform with the surface to be tested facing the indenter. The indenter was brought in contact with the specimen surface. A load of 0.1 $\mathrm{N}$ was applied to the surface for 10 seconds. Five indentations, equally spaced over a circle, were made on the surface of each specimen. The surface hardness test was carried out at the following intervals: 1 hour after mixing (before immersion) and then subsequently at 6 hours and at 1, 2, 3, 4 , and 7 days. Gradual changes in surface microhardness were recorded at each time interval. The long period of immersion here was performed to examine the extensive effect of those agents. During the test period, the plastic storage pots, containing the specimens for investigation, were kept in an incubator at $37^{\circ} \mathrm{C}$ before hardness measurements were made. In order to maintain the original $\mathrm{pH}$ level of the storage solution, the juices were refreshed daily throughout the experiment.

\section{Surface micromorphology analysis}

Using scanning electron microscopy (SEM) (JSM model 5800LV, JEOL, Tokyo, Japan), the effect of each storage agent on the surface micro- morphology of the materials before and after immersion were determined. Three specimens of each restorative material from each of the four storage media at day 3 and 7 were examined. The specimens were rinsed with distilled water for 5 minutes, dried and fixed onto an aluminium cylinder (13 $\mathrm{mm}$ in diameter and $10 \mathrm{~mm}$ in height). Consequently, the specimens were sputter-coated with a gold-palladium alloy (SPI-Module sputter, SPI Supplies, West Chester, PA, USA) and examined using SEM.

\section{Statistical analysis}

Surface microhardness values were tested for significant differences (at $\alpha=.05$ ) using a two-way ANOVA with repeated measurement and Tukey's Honestly Significant Difference (HSD) for multiple comparisons.

\section{RESULTS}

Both freshly prepared juices were highly acidic solutions (Table 2). The mean $\mathrm{pH}$ and standard deviations (SD) of green mango juice was 2.56 (0.08), pineapple juice was $3.68(0.08)$ and citrate buffer solution was 5.00 (0.02). Titratable acidity of the storage media with $1 \mathrm{~N} \mathrm{NaOH}$ is shown in Table 2 and Figure 1.

The results of two-way ANOVA with repeated measurement revealed that there were statistically significant differences among the four types of materials, the four types of storage media, and the interactions between type of material and type of storage media ( $P<.001$ for all comparisons). The effect of the various storage media on surface microhardness of the four types of restorative materials over 7 days is shown in Tables 3 through 6. Before immersion (at 1 hour), Valiant-Ph.D. had the highest surface hardness value, followed by Filtek Z250, while Ketac-S was comparable to Fuji II LC. After immersion 16 hours through 7 days), all materials tested had various softening characteristics depending on the types of storage media except for the Valiant-Ph.D. amalgam. For Ketac-S (Table 3), surface hardness significantly reduced after immersion in green mango juice for 6 hours $(P=.02)$ and in citrate buffer solution for 1 day $(P=.03)$. It was noted that changes in surface hardness for Ketac-S were not recordable after immersion in green mango juice for 2 days, while immersion in pineapple juice produced a 
significant hardness reduction at day $2(P=.001)$. The result of Fuji II LC (Table 4) were similar to those of Ketac-S; surface hardness significantly reduced after immersion in green mango juice for 6 hours $(P=.03)$ and in citrate buffer solution for 1 day $(P=.001)$. After pineapple juice immersion for 2 days, the hardness value of Fuji II LC reduced significantly $(P=.001)$. The surface hardness of Filtek Z250 (Table 5) significantly reduced after immersion in citrate buffer solution and pineapple juice for 3 days ( $P<.001$ for both comparisons) and after immersion in mango juice for 2 days $(P<.001)$. On the contrary, Valiant-Ph.D. became harder between 1 hour and 1 day, and there was little alteration in surface hardness up to the day 7 evaluation. Surface hardness after immersion in green mango juice seemed to have the lowest value, but there was no significant difference among the four storage media $(P=.67)$.

The effect of the four storage agents on the hardness values of the evaluated materials was tested by Tukey's HSD multiple comparison. This

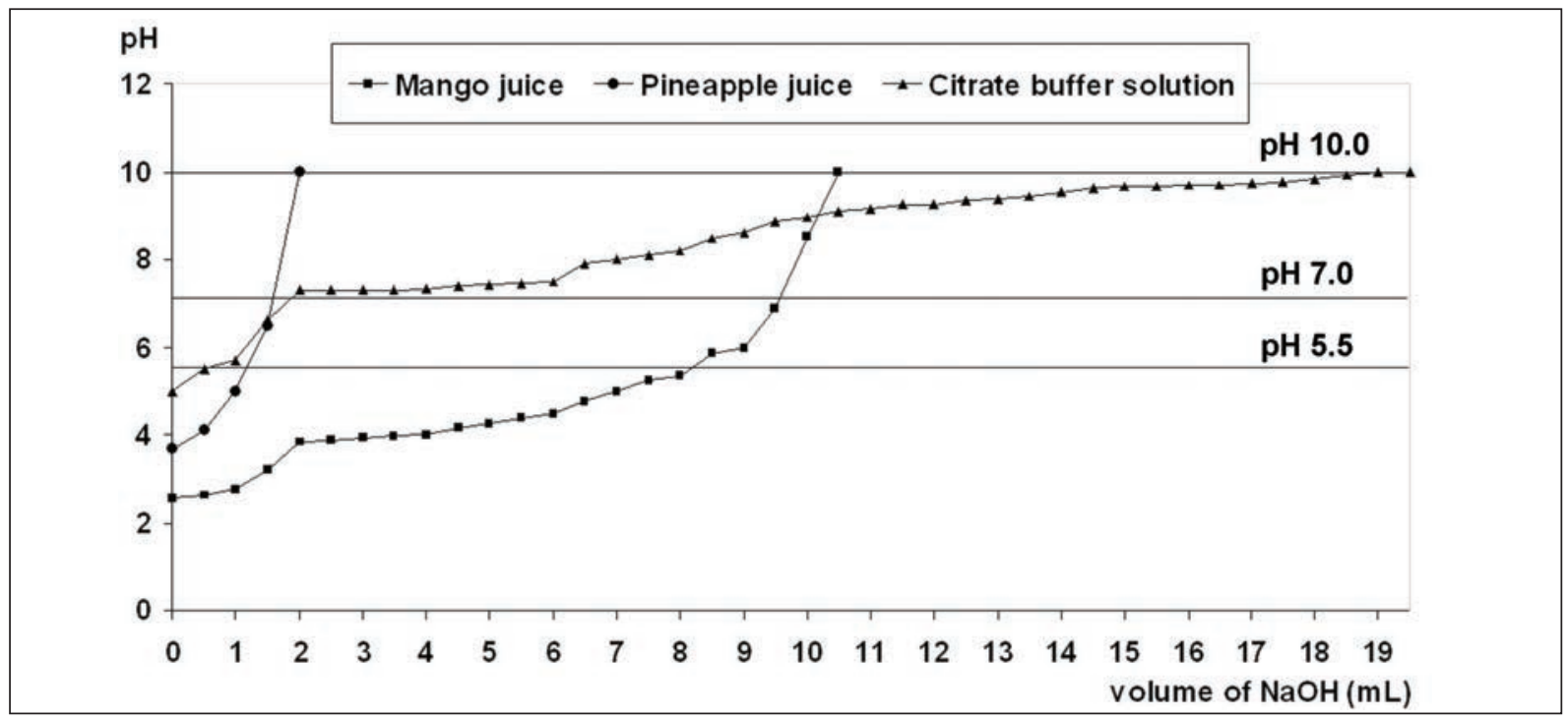

Figure 1. The graph of titration for three storage media showed the amount of $\mathrm{NaOH}$ solution required to raise the $\mathrm{pH}$ of each solution up to $\mathrm{pH} 5.5,7.0$ and 10.0 .

Table 2. Mean (SD) of the total volume of $1 \mathrm{~N} \mathrm{NaOH}(\mathrm{mL})$ required to reach $\mathrm{pH} 5.5,7.0$ and 10.0 of acidic agents tested.

\begin{tabular}{lccc}
\hline & \multicolumn{3}{c}{ Mean (SD) of volume of $1 \mathrm{~N} \mathrm{NaOH}(\mathrm{ml})$ required } \\
\hline Storage media & $\mathrm{pH} 5.5$ & $\mathrm{pH} 7.0$ & $\mathrm{pH} \mathrm{10.0}$ \\
\hline $\begin{array}{l}\text { Citrate buffer solution } \\
\text { pH 5.00 (0.02) }\end{array}$ & $0.56(0.06)$ & $1.79(0.05)$ & $19.22(0.05)$ \\
$\begin{array}{l}\text { Green mango juice } \\
\text { pH 2.56 (0.08) }\end{array}$ & $8.31(0.54)$ & $10.36(0.62)$ & $11.03(0.77)$ \\
$\begin{array}{l}\text { Pineapple juice } \\
\text { pH 3.68 (0.08) }\end{array}$ & $1.24(0.25)$ & $1.66(0.39)$ & $1.94(0.39)$ \\
\hline
\end{tabular}

Table 3. Mean (SD) surface hardness $\left(\mathrm{kg} / \mathrm{mm}^{2}\right)$ of Ketac-S immersed in various storage media over a period of 7 days.

\begin{tabular}{|c|c|c|c|c|c|c|c|}
\hline \multirow[b]{2}{*}{ Storage media } & \multicolumn{7}{|c|}{ Mean (SD) surface hardness $\left(\mathrm{kg} / \mathrm{mm}^{2}\right.$ ) } \\
\hline & $\begin{array}{c}\text { Before } \\
\text { immersion }\end{array}$ & 6 hours & 1 day & 2 days & 3 days & 4 days & 7 days \\
\hline Deionized water & $52.04(2.39)$ & $54.60(2.73)$ & $57.54(1.81)$ & $57.05(4.79)$ & $57.84(5.30)$ & $57.26(0.64)$ & $57.97(2.58)^{a}$ \\
\hline $\begin{array}{l}\text { Citrate buffer } \\
\text { solution }\end{array}$ & $53.52(2.45)$ & $50.73(1.68)$ & $41.36(1.99)^{*}$ & $29.22(1.30)^{*}$ & $28.32(1.89)^{*}$ & $27.01(6.07)^{*}$ & $26.18(4.15)^{*}, \mathrm{c}$ \\
\hline $\begin{array}{l}\text { Green mango } \\
\text { juice }\end{array}$ & $54.45(4.97)$ & $33.54(1.11)^{*}$ & $27.75(0.90)^{*}$ & & Soft and unable & measurement & \\
\hline Pineapple juice & $53.84(2.32)$ & $53.06(3.77)$ & $48.97(3.36)$ & $47.66(2.42)^{*}$ & $39.23(1.71)^{*}$ & $35.20(1.62)^{*}$ & $31.35(1.63)^{*}, \mathrm{~b}$ \\
\hline
\end{tabular}

* indicates significant difference compared to before immersion for each storage media (in rows) according to Tukey HSD test (P<.05). a,b,c indicate significant differences among 4 storage media (in columns) according to Tukey HSD test $(P<.05)$. 
revealed that the green mango juice provided the greatest reduction in hardness value for all materials ( $P<.001$ for all comparisons). The deionized water produced the least reduction of hardness value for all materials, followed by pineapple juice $(P<.001$ for all comparisons). According to the extent of changes in surface hardness, the four restorative materials can be arranged as follows: Ketac-S > Fuji II LC > Filtek Z250 > Valiant-Ph.D.
The ranking order of the erosive potential of the storage agents was as follows: mango juice $>$ citrate buffer solution $>$ pineapple juice $>$ deionized water.

Figures 1 through 4 show the gradual surface changes of the various restorative materials tested. Before immersion, the Ketac-S and the Valient-Ph.D. specimens demonstrated rough surfaces and the protrusion of filler particles (Fig-
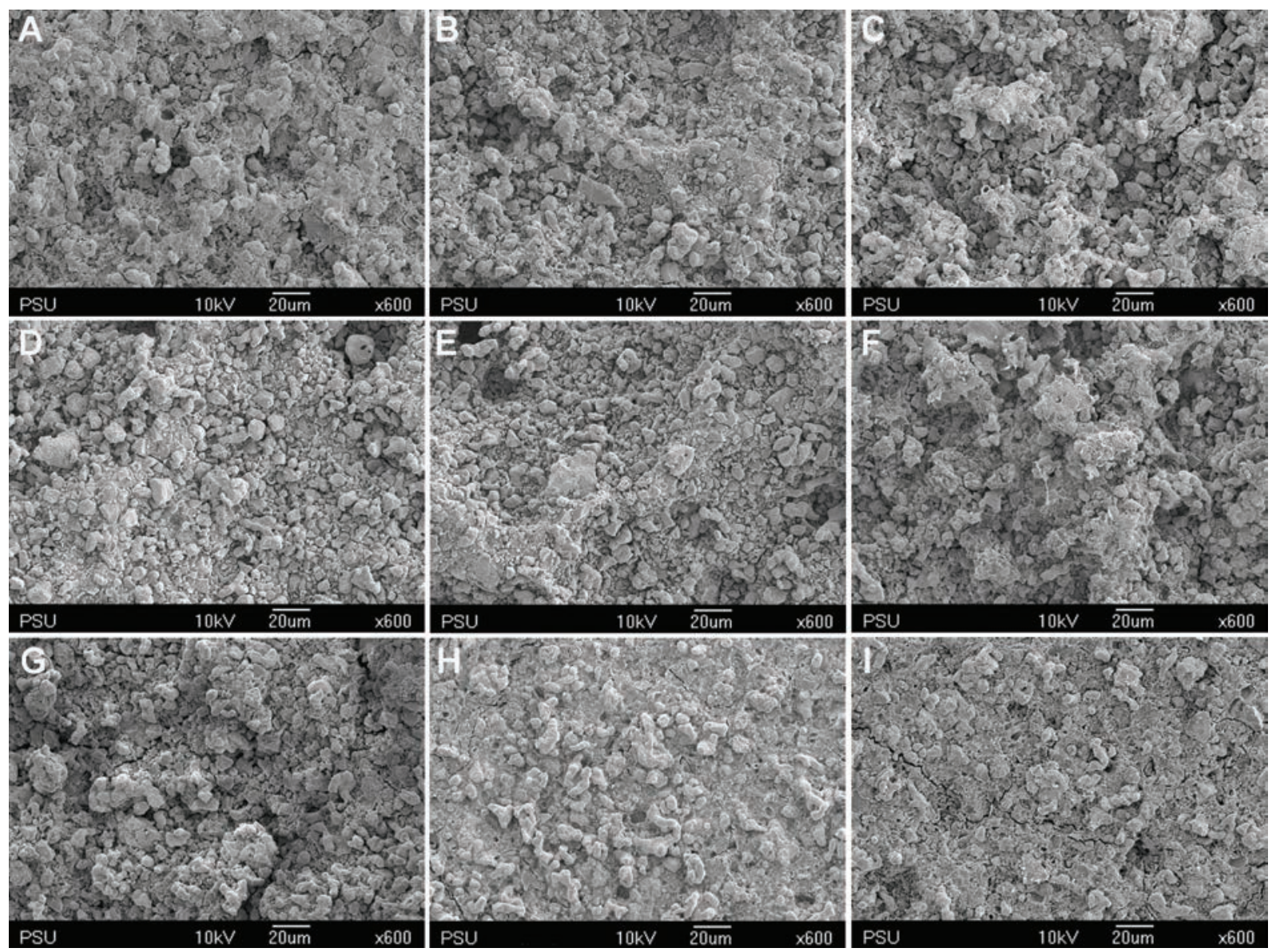

Figure 2. SEM photomicrographs of Ketac-S before and after immersion in various storage media for 3 and 7 days ( $\times 600$ magnification). A- Before immersion, B- In deionized water for 3 days, C- In deionized water for 7 days, D- In citrate buffer solution for 3 days, E- In citrate buffer solution for 7 days, F- In green mango juice for 3 days, G- In green mango juice for 7 days, $\mathrm{H}$ - In pineapple juice for 3 days, I- In pineapple juice for 7 days.

Table 4. Mean (SD) surface hardness ( $\left.\mathrm{kg} / \mathrm{mm}^{2}\right)$ of Fuji II LC immersed in various storage media over a period of 7 days.

\begin{tabular}{|c|c|c|c|c|c|c|c|}
\hline \multirow[b]{2}{*}{ Storage media } & \multicolumn{7}{|c|}{ Mean (SD) surface hardness $\left(\mathrm{kg} / \mathrm{mm}^{2}\right)$} \\
\hline & $\begin{array}{c}\text { Before } \\
\text { immersion }\end{array}$ & 6 hours & 1 day & 2 days & 3 days & 4 days & 7 days \\
\hline $\begin{array}{l}\text { Deionized } \\
\text { water }\end{array}$ & $50.38(1.34)$ & $50.64(1.42)$ & $55.10(0.61)$ & $55.58(0.94)$ & $56.03(0.33)$ & $56.29(0.57)$ & $55.75(0.75)^{a}$ \\
\hline $\begin{array}{l}\text { Citrate buffer } \\
\text { solution }\end{array}$ & $49.44(1.80)$ & $45.78(2.48)$ & $37.71(0.82)^{*}$ & $28.32(2.96)^{*}$ & $18.22(1.92)^{*}$ & $14.15(2.96)^{*}$ & $12.52(1.17)^{*}, \mathrm{c}$ \\
\hline $\begin{array}{l}\text { Green mango } \\
\text { juice }\end{array}$ & $51.48(1.72)$ & $26.65(1.05)^{*}$ & $19.24(1.06)^{*}$ & $13.60(1.15)^{*}$ & $9.67(1.01)^{*}$ & $8.02(0.89)^{*}$ & $6.37(0.89) *$, \\
\hline Pineapple juice & $50.87(4.26)$ & $54.02(3.84)$ & $43.89(2.98)$ & $30.08(1.52)^{*}$ & $26.03(1.59)^{*}$ & $25.17(0.87)^{*}$ & $19.76(1.26) *$, \\
\hline
\end{tabular}

* indicates significant difference compared to before immersion for each storage media (in rows) according to Tukey HSD test (P<.05). $a, b, c, d$ indicate significant differences among 4 storage media (in columns) according to Tukey HSD test ( $P<.05$ ). 
ures $1 \mathrm{~A}$ and 4A, respectively). The Fuji II LC specimens showed a few rough surfaces (Figure 2A), while the Filtek Z250 specimens demonstrated the smoothest surfaces (Figure 3A). After immersion in the various storage media for 3 and 7 days, the SEM photomicrographs of Fuji II LC showed more rough surfaces with pits, which increased with time in the citrate buffer solution (Figures 2D and $2 E$, respectively) and the mango juice (Figures
$2 F$ and $2 G$, respectivelyl. Cracks seen on the surfaces of the glass ionomer cements were artifacts caused by vacuum dehydration during processing. Similar results were found for Ketac-S (Figures 1D through 1G) and Valiant-Ph.D. (Figures 4D through 4G); after citrate buffer solution and mango juice immersion for 3 and 7 days, their SEM photomicrographs displayed roughening patterns which increased with immersion time. Filler par-

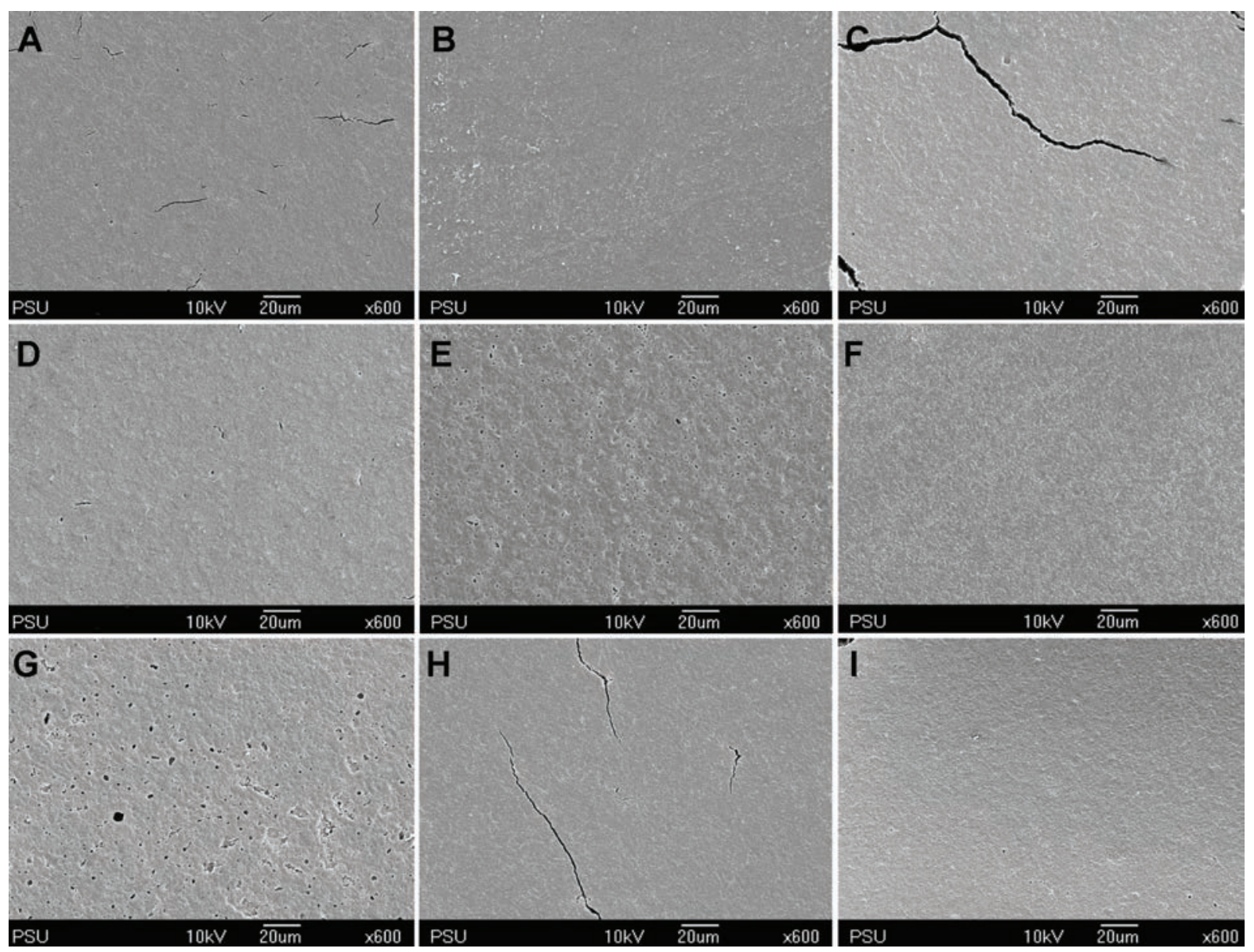

Figure 3. SEM photomicrographs of Fuji II LC before and after immersion in various storage media for 3 and 7 days (x600 magnification). A- Before immersion, B- In deionized water for 3 days, C- In deionized water for 7 days, D- In citrate buffer solution for 3 days, E- In citrate buffer solution for 7 days, F- In green mango juice for 3 days, G- In green mango juice for 7 days, $\mathrm{H}$ - In pineapple juice for 3 days, I- In pineapple juice for 7 days.

Table 5. Mean (SD) surface hardness ( $\mathrm{kg} / \mathrm{mm}^{2}$ ) of Filtek Z250 immersed in various storage media over a period of 7 days.

\begin{tabular}{|c|c|c|c|c|c|c|c|}
\hline \multirow[b]{2}{*}{ Storage media } & \multicolumn{7}{|c|}{ Mean (SD) surface hardness $\left(\mathrm{kg} / \mathrm{mm}^{2}\right.$ ) } \\
\hline & Before immersion & 6 hours & 1 day & 2 days & 3 days & 4 days & 7 days \\
\hline $\begin{array}{l}\text { Deionized } \\
\text { water }\end{array}$ & $83.75(2.65)$ & $85.14(2.66)$ & $87.40(1.39)$ & $86.46(1.94)$ & $87.96(2.21)$ & $88.88(1.84)$ & $89.54(1.83)^{\mathrm{a}}$ \\
\hline $\begin{array}{l}\text { Citrate buffer } \\
\text { solution }\end{array}$ & $82.04(2.56)$ & $82.90(1.89)$ & $80.70(2.34)$ & $79.18(2.03)$ & $77.82(1.02)^{*}$ & $70.04(0.52)^{*}$ & $69.10(0.85)^{*}, \mathrm{~b}$ \\
\hline $\begin{array}{l}\text { Green mango } \\
\text { juice }\end{array}$ & $82.67(3.42)$ & $82.03(0.45)$ & $80.37(1.04)$ & $76.58(1.97)^{*}$ & $69.49(1.85)^{*}$ & $69.78(0.66)^{*}$ & $68.04(1.61)^{*}$, \\
\hline Pineapple juice & $81.04(2.34)$ & $81.78(2.88)$ & $80.26(1.29)$ & 79.72 (1.78) & $70.76(3.18)^{*}$ & $70.30(1.53)^{*}$ & $68.94(2.59) *$, \\
\hline
\end{tabular}

* indicates significant difference compared to before immersion for each storage media (in rows) according to Tukey HSD test (P<.05). $a, b$ indicate significant differences among 4 storage media (in columns) according to Tukey HSD test ( $<<.05)$. 
ticles were more clearly seen after 7 days immersion than after 3 days immersion. Conversely, the Filtek Z250 specimens (Figure 3) still showed mostly smooth surfaces after 3 and 7 days immersion in all storage media. It was noted that after the materials were tested and immersed in pineapple juice (Figures 1I, 2I, 3I and 4I), the specimen surface seemed to have a "plaque-like" covering layer.

\section{DISCUSSION}

In the oral cavity, restorative materials are exposed to varying environments. Two such variables are changes in temperature and acidic-base conditions from food and drinks. Therefore, the restorative materials used in the mouth should resist or show minimal change in these situations. In the present study, this method was performed solely to examine erosion by static immersion of
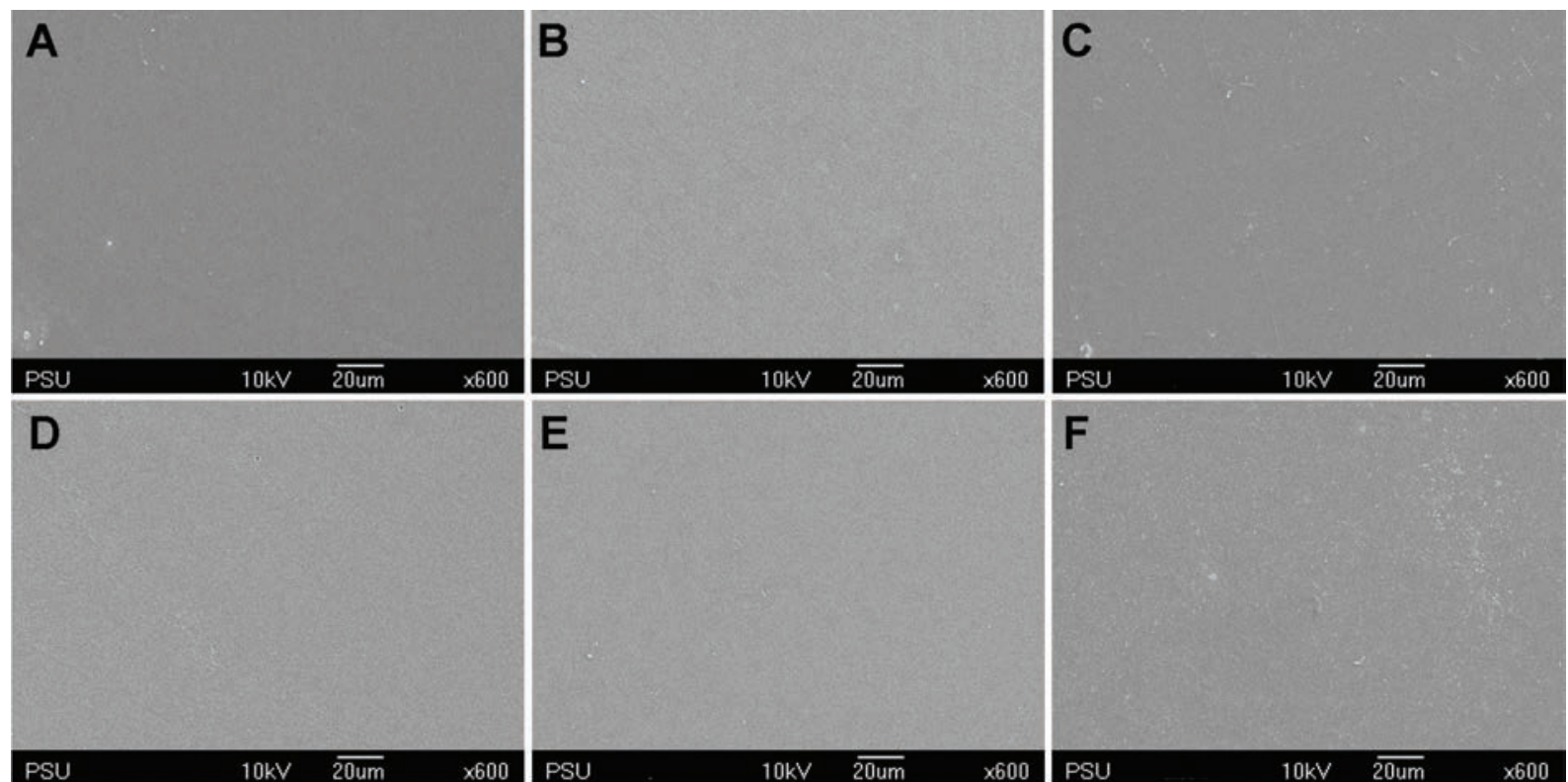

G
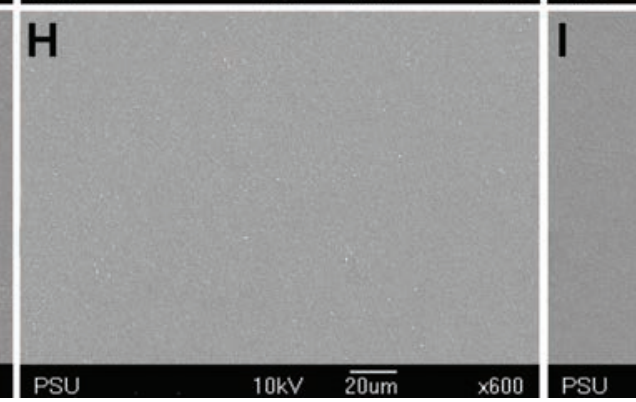

Figure 4. SEM photomicrographs of Filtek Z250 before and after immersion in various storage media for 3 and 7 days (x600 magnification). A- Before immersion, B- In deionized water for 3 days, C- In deionized water for 7 days, D- In citrate buffer solution for 3 days, E- In citrate buffer solution for 7 days, F- In green mango juice for 3 days, G- In green mango juice for 7 days, $\mathrm{H}$ - In pineapple juice for 3 days, I- In pineapple juice for 7 days.

Table 6. Mean (SD) surface hardness (kg/mm²) of Valiant-Ph.D. immersed in various storage media over a period of 7 days.

\begin{tabular}{|c|c|c|c|c|c|c|c|}
\hline \multirow[b]{2}{*}{ Storage media } & \multicolumn{7}{|c|}{ Mean (SD) surface hardness $\left(\mathrm{kg} / \mathrm{mm}^{2}\right)$} \\
\hline & $\begin{array}{c}\text { Before } \\
\text { immersion }\end{array}$ & 6 hours & 1 day & 2 days & 3 days & 4 days & 7 days \\
\hline $\begin{array}{l}\text { Deionized } \\
\text { water }\end{array}$ & $99.78(2.59)$ & $116.67(5.28)^{*}$ & $196.87(6.41)^{*}$ & $198.68(6.69)^{*}$ & $200.77(7.12)^{*}$ & $199.18(3.46)^{*}$ & $200.83(7.95)^{*}$ \\
\hline $\begin{array}{l}\text { Citrate } \\
\text { buffer solution }\end{array}$ & $99.52(4.01)$ & $116.45(3.11)^{*}$ & $198.86(5.54)^{*}$ & $198.54(6.02)^{*}$ & $191.69(9.15)^{*}$ & $195.02(7.01)^{*}$ & $193.61(8.48)^{*}$ \\
\hline $\begin{array}{l}\text { Green } \\
\text { mango juice }\end{array}$ & $98.59(1.74)$ & $105.14(2.45)^{*}$ & $188.41(5.98)^{*}$ & $185.88(4.53)^{*}$ & $190.06(8.08)^{*}$ & $193.07(3.29)^{*}$ & $191.99(5.76)^{*}$ \\
\hline Pineapple juice & $98.76(2.39)$ & $122.56(4.68)^{*}$ & $197.26(4.65)^{*}$ & $196.48(2.08)^{*}$ & $197.66(7.14)^{*}$ & $191.67(3.01)^{*}$ & $192.57(3.25)^{*}$ \\
\hline
\end{tabular}

* indicates significant difference compared to before immersion for each storage media (in rows) according to Tukey HSD test (P<.05). 
the restorative materials in the solutions over a period of 7 days and to detect subsequent changes in hardness. This study did not aim to investigate the effects of attrition from chewing habits because the oral cavity is a complex environment and is difficult to simulate experimentally. Therefore, a long immersion time was used as an alternative for presenting the extensive effect of acidic solutions.

The four restorative materials selected in the present study are those most commonly used for restoring teeth that have erosive conditions. ${ }^{10}$ In this present study, the results showed that immersion of restorative materials in the acidic agents tested could reduce the surface hardness and could cause rough surface which increased with time, as observed with SEM photomicrographs. Ketac-S metal-reinforced glass ionomer cement and Fuji II LC resin-modified glass ionomer cement decreased in surface hardness more than Valiant-Ph.D. amalgam and Fltek Z250 resin composite. In the comparison between Ketac-S and Fuji II LC, the results showed that Ketac-S was degraded to a greater extent by acidic agents than was Fuji II LC. This confirmed the result of Ketac$S$ at day 2 wherein the hardness value could not be measured. Possible reasons for those results might be the difference in the composition of the materials and the set structure of each material, including the titratable acidity of the acidic agents.

It has been generally accepted that titratable acidity is a better indicator of erosive potential than $\mathrm{pH}$ alone. ${ }^{25,26}$ From the present study, green mango juice provided the greatest titratable acidity and also degraded the restorative materials tested (except Valiant-Ph.D. amalgam) more than the other storage media. Although pineapple juice had a lower $\mathrm{pH}$ value (3.68) than citrate buffer solution (5.00), the pineapple juice had a lesser titratable acidity than the citrate buffer solution. Therefore, pineapple juice seemed to be less effective in degrading the materials. Another pos-
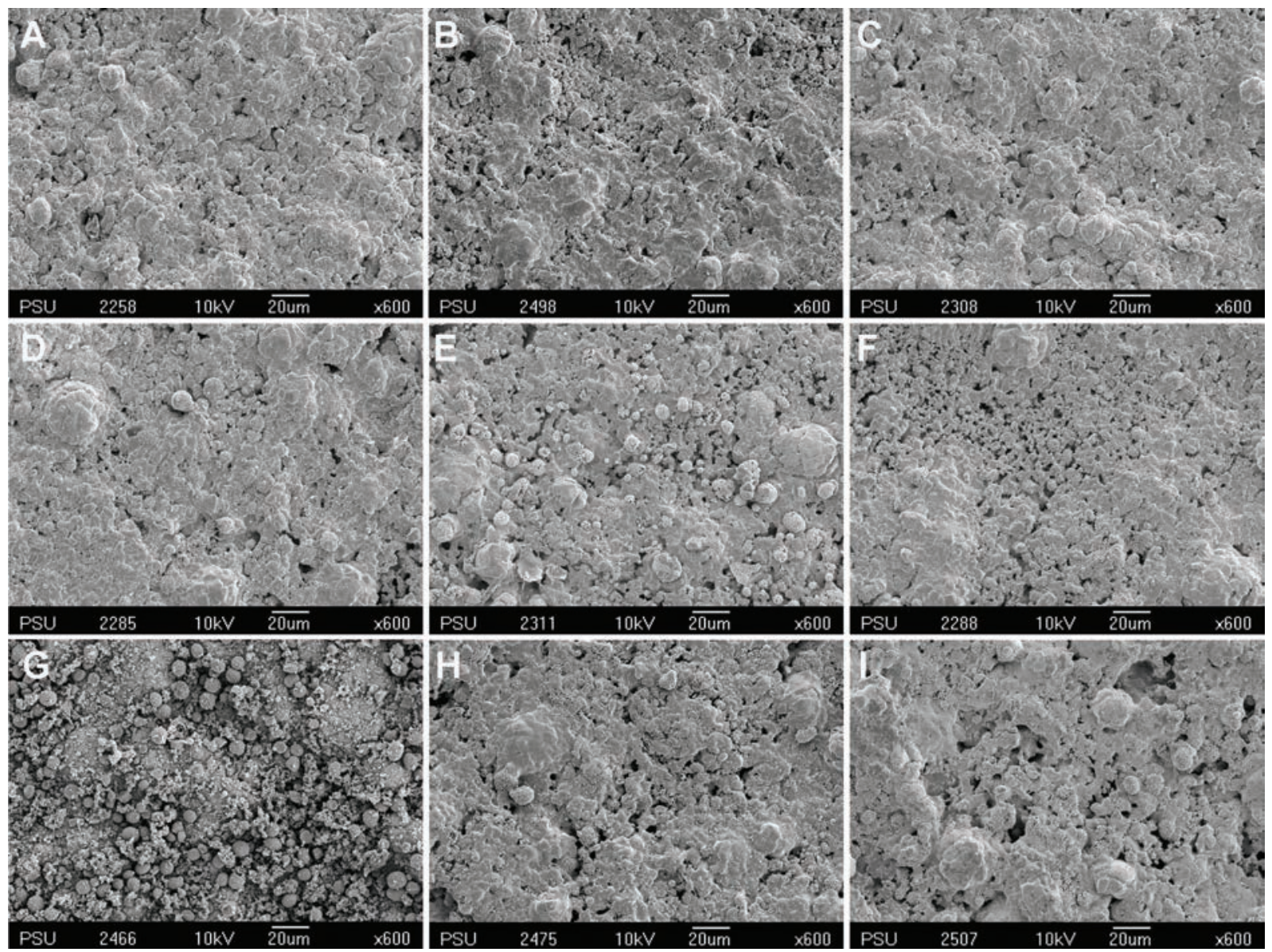

Figure 5. SEM photomicrographs of Valiant-Ph.D. before and after immersion in various storage media for 3 and 7 days ( $\times 600$ magnification). A- Before immersion, B- In deionized water for 3 days, C- In deionized water for 7 days, D- In citrate buffer solution for 3 days, E- In citrate buffer solution for 7 days, F- In green mango juice for 3 days, G- In green mango juice for 7 days, $\mathrm{H}$ - In pineapple juice for 3 days, I- In pineapple juice for 7 days. 
sible explanation might be that pineapple contains some components that may provide a protective effect against erosion. This explanation is consistent with the SEM photomicrographs which observed a "plaque-like" covering layer. Therefore, further investigation regarding this phenomenon is required.

In this present study, after Ketac-S was immersed for 2 days or more in green mango juice, it became increasingly soft until the hardness could no longer be measured. This may result from extensive dissolution of this material by acid attack at the interfacial bonding between the silver alloy fillers and the polyacrylate matrix. ${ }^{27}$ These results suggest that in clinical decision-making, this material may not be suitable for patients who have the habit of eating sour fruits, which has acidic ingredients, like green mangoes. With Fuji II LC, the reduction in surface hardness may be caused by a selective attack on the polysalt matrix among the residual particles. ${ }^{28}$ The polysalt matrix of the set cement results from the formation of contact cation-anion ion pairs or complexes between the carboxylic groups of the polyalkenoic acid and metallic ions, especially trivalent aluminium, leached from the glass particles. Another possible explanation is that resin-modified glass ionomer cement may release additional fluoride after immersion in acidic environments. This can result from the dissolution of matrix-forming constituents within the restorative material. ${ }^{28}$ However, some research indicates that it may also resist acid better than a conventional glass ionomer cement, as was found in studies by Shabanian and Richards, ${ }^{12}$ McKenzie et $\mathrm{al}^{13}$ and Aliping-McKenzie et al. ${ }^{29}$

As regards Filtek Z250 resin composite, the deterioration of its physical and mechanical properties could be due to a hydrolytic breakdown of the bond between silane and the filler particles, filler-matrix debonding, or even hydrolytic degradation of the fillers. ${ }^{30,31}$ Alternately, it could be due to chemical degradation occurring via hydrolysis. Progressive degradation altered the microstructure of the composite bulk through the formation of pores. ${ }^{31}$ In this present study, Filtek Z250 resisted acid solution better than did Fuji II LC, which is consistent with the results found in other studies. ${ }^{12,15,32,33}$

Here in this study, surface hardness results showed that amalgam was harder than the other materials in all storage solutions after immersion for all evaluated time periods. This was because the material was not yet fully set until 24 hours. The results of this present study showed that immersion in the acidic agents tested could not degrade this material. This demonstrates that Valiant-Ph.D. tends to tolerate acidic conditions better than the other three materials.

The most important finding in this in vitro study was that Valiant-Ph.D. amalgam and Filtek Z250 resin composite could withstand acidic solutions better than Ketac-S metal-reinforced glass ionomer cement and Fuji II LC resin-modified glass ionomer cement. This in vitro study thus might recommend that, in terms of resistance to degradation, amalgam or resin composite should be the materials of choice while restoring teeth affected by erosion. However, the degradation of materials is not the only factor involved in making this choice. Operator preference and patient factors should also be taken into consideration.

It must be noted that there were some limitations to this present study. The role of saliva was not taken into consideration. ${ }^{34}$ Furthermore, the oral cavity presents a challenging testing environment that cannot be precisely replicated under experimental conditions. For example, temperature changes, $\mathrm{pH}$ level, and the presence of water in the oral cavity may also considerably affect properties of restorations. In addition, the present study evaluated only in vitro effects. Further studies are required to examine the effects of sour fruit juice in vivo.

\section{CONCLUSIONS}

Within the limitations of this study, the following conclusions were drawn:

- The acidic agents tested (citrate buffer solution, green mango juice, and pineapple juicel have an effect on the reduction of surface microhardness of restorative materials.

- Amalgam (Valiant-Ph.D.) and resin composite (Filtek Z250) were more resistant to acid attacks, and were better than both types of glass ionomer cement (Ketac-S and Fuji II LC).

- For clinical decision-making, amalgam and resin composite are the most suitable materials for restorations in patients who are at high risk for erosive conditions. 


\section{ACKNOWLEDGEMENTS}

The authors would like to thank Professor Peter A. Leggat, James Cook University, Townsville, Australia, for his suggestions in the data analysis and for proofing the manuscript. This study was supported by a grant from Prince of Songkla University.

\section{REFERENCES}

1. ten Cate JM, Imfeld T. Dental erosion, summary. Eur J Oral Sci 1996;104:241-244.

2. Milosevic A. Tooth wear: Aetiology and presentation. Dent Update 1998;25:6-11.

3. Jaeggi T, Lussi A. Prevalence, incidence and distribution of erosion. Monogr Oral Sci 2006;20:44-65.

4. Lambrechts $P$, van Meerbeek B, Perdigão J, Gladys S, Braem M, Vanherle G. Restorative therapy for erosive lesions. Eur J Oral Sci 1996;104:229-240.

5. Powers JM, Sakaguchi RL. Craig's restorative dental materials, 12 $2^{\text {th }}$ Ed. St. Louis: Elsevier Mosby, 2006:192-194.

6. Saito S, Tosaki S, Hirota K. Characteristics of glass-ionomer cements. In: Davidson CL, Mjör IA, eds. Advances in glass-ionomer cements. Chicago: Quintessence, 1999:1623.

7. McLean JW, Wilson AD. Glass ionomer cements. Br Dent J 2004;196:514-515

8. McLean JW, Gasser 0. Glass-cermet cements. Quintessence Int 1985;16:333-343.

9. Walls AW, Adamson J, McCabe JF, Murray JJ. The properties of a glass polyalkenoate (ionomer) cement incorporating sintered metallic particles. Dent Mater 1987;3:113-116.

10. Williams JA, Billington RW, Pearson GJ. The comparative strengths of commercial glass-ionomer cements with and without metal additions. Br Dent J 1992;172:279-282.

11. Wilson AD. Resin-modified glass-ionomer cements. Int $J$ Prosthodont 1990;3:425-429.

12. Shabanian M, Richards LC. In vitro wear rates of materials under different loads and varying $\mathrm{pH}$. $J$ Prosthet Dent 2002;87:650-656.

13. McKenzie MA, Linden RW, Nicholson JW. The physical properties of conventional and resin-modified glass-ionomer dental cements stored in saliva, proprietary acidic beverages, saline and water. Biomaterials 2003;24:40634069.

14. Ferracane JL. Materials in Dentistry: Principles and applications. Philadelphia: Lippincott Williams and Willkins, 2001:102-109.

15. Mante MO, Saleh N, Tanna NK, Mante FK. Softening patterns of light cured glass ionomer cements. Dent Mater 1999;15:303-309.
16. Wongkhantee S, Patanapiradej V, Maneenut C, Tantbirojn D. Effect of acidic food and drinks on surface hardness of enamel, dentine, and tooth-coloured filling materials. $J$ Dent 2006;34:214-220.

17. West NX, Hughes JA, Addy M. The effect of $\mathrm{pH}$ on the erosion of dentine and enamel by dietary acids in vitro. $J$ Oral Rehabil 2001;28:860-864.

18. Amaechi BT, Higham SM, Edgar WM. Factor influencing the development of dental erosion in vitro: Enamel type, temperature and exposure time. J Oral Rehabil 1999;26:624630.

19. Hughes JA, Jandt KD, Baker N, Parker D, Newcombe RG, Eisenburger M, Addy M. Further modification to soft drinks to minimize erosion. A study in situ. Caries Res 2002;36:7074.

20. Kunzel W, Cruz MS, Fischer T. Dental erosion in Cuban children associated with excessive consumption of oranges. Eur J Oral Sci 2000;108:104-109.

21. Bell EJ, Kaidonis J, Townsend G, Richards L. Comparison of exposed dentinal surfaces resulting from abrasion and erosion. Aust Dent J 1998;43:362-366.

22. Kieser JA, Dennison KJ, Kaidonis JA, Huang D, Herbison PG, Tayles NG. Patterns of dental wear in the early Maori dentition. Int J Osteoarchaeol 2001;11:206-217.

23. Chuajedong P, Kedjarune-Leggat U, Kertpon D, Chongsuvivatwong V, Benjakul P. Associated factors of tooth wear in southern Thailand. J Oral Rehabil 2002;29:997-1002.

24. Cairns AM, Watson SL, Creanor SL, Foye RH. The pH and titratable acidity of a range of diluting drinks and their potential effect on dental erosion. J Dent 2002;30:313-317.

25. Grobler SR, Jenkins GN, Kotze D. The effects of the composition and method of drinking of soft drinks on plaque $\mathrm{pH}$. Br Dent J 1985;158:293-296.

26. Edwards M, Creanor SL, Foye RH, Gilmour WH. Buffering capacities of soft drinks: the potential influence on dental erosion. J Oral Rehabil 1999;26:923-927.

27. Sazak-Öveçoḡlu H, Günday M, Öveçoḡlu ML, Tarçin B. Chemical degradation of restorative materials. Key Eng Mater 2004;264-8:2009-2012.

28. Wilde MG, Delfino CS, Sassi JF, Garcia PP, Palma-Dibb RG. Influence of $0.05 \%$ sodium fluoride solutions on microhardness of resin-modified glass ionomer cements. $J$ Mater Sci Mater Med 2006;17:869-873.

29. Aliping-McKenzie M, Linden RW, Nicholson JW. The effect of Coca-Cola and fruit juices on the surface hardness of glass-ionomers and 'compomers'. J Oral Rehabil 2004;31:1046-1052.

30. Söderholm KJ, Zigan M, Ragan M, Fischlschweiger W, Bergman M. Hydrolytic degradation of dental composites. J Dent Res 1984;63:1248-1254. 
31. Medeiros IS, Gomes MN, Loguercio AD, Filho LE. Diametral tensile strength and Vickers hardness of a composite after storage in different solutions. J Oral Sci 2007;49:6166.

32. Bagheri R, Tyas MJ, Burrow MF. Comparison of the effect of storage media on hardness and shear punch strength of tooth-colored restorative materials. Am J Dent 2007;20:329-334.

33. Honório HM, Rios D, Francisconi LF, Magalhães $A C$, Machado MA, Buzalaf MA. Effect of prolonged erosive $\mathrm{pH}$ cycling on different restorative materials. J Oral Rehabil 2008;35:947-953.

34. Piangprach T, Hengtrakool C, Kukiattrakoon B, KedjaruneLeggat $U$. The effect of salivary factors on dental erosion in various age groups and tooth surfaces. J Am Dent Assoc 2009;140:1137-1143. 